\title{
Guidance and counseling profession: a philosophy and professional challenges in the future
}

\author{
Alfaiz $^{*}$ \\ ${ }^{1}$ STKIP PGRI Sumatera Barat \\ *)Corresponding author, ఏe-mail: alfaiz.science.icp@gmail.com
}

\begin{abstract}
As a science, guidance and counseling has become a helping profession that has been approved by society in the world, especially in academic and practical profession. In the begining, counseling was growth and developed in America which concern in how to place someone qualified with one work, this focus was to make a career decision through a counseling interview and assessmen, and also growth to help people to make decision and learn something new about them self in theraputic process, with psychological threatment and technique. As a multidicipliner science, counseling more flexible than any other dicipline. But in this 21 century counseling as a profession that has been challenges by something that must admit and counselor must know about this, such counseling multicultural, indigineous science that become an interesting subject, counseling has a value contract or not?, and counseling to educate and make client learn something or something that client found by them self? With liberate counseling?. This article will discuss more further about paradigm of guidance and counseling profession with point of view a philosophy and professional challenges in the future that must be understanding and face in the future without lose our cultural and religion values.
\end{abstract}

Keyword: counseling, profession, philosophy, professional challenges and learning

How to Cite: Alfaiz, A. (2018). Guidance and counseling profession: a philosophy and professional challenges in the future. Couns-Edu: International Journal of Counseling and Education, 3(1): pp. 41-47. DOI: https://doi.org/10.23916/0020180313420

\section{Introduction}

Development of human life that involving of mind, emotional, spiritual and physical ability determines the changes and behaviors that create human beings as creatures who can mobilize their activities to achieve their goals. A balance between cognitive, emotional and spiritual is an important factor in the individual's maturity to seek truth in life, the process of seeking truth in life is a process of thinking using reason in answering every question and solving problems in life (Suriasumantri, 1982).

Thinking that kind of thing is a systematic, critical and causal process of philosophy, so that the individual who has the ability to think, not only finds the truth, but also anticipates and can even predict the assumption of what events will happen when the individual is doing certain behavior. This thinking process is called in the science of counseling psychology with metacognitive ability (forethought) (Bandura, 2006). 


\section{COUNS-EDU}

Vol.3, No.1, 2018

Available online: http://journal.konselor.or.id/index.php/counsedu

Alfaiz Alfaiz

Such thinking, raises the concept that human beings are able to predict and anticipate from behaviors that are done and how environmental behavior is otherwise. This process is philosophical thinking and study in counseling to make people have the behavior as an agent for himself. Counseling in the present is indispensable and there are many debates to how guidance and counseling as a profession and science? And whether counseling is able to answer today's challenges (postmodernism)? Is the development of counseling in Indonesia able to change the face of education, social culture, and even the system in Indonesia ?. So in this paper will explain the position and development of guidance and counseling as a profession and science seen from the point of view of philosophy of science and in the view of education itself.

\section{Discussion}

\section{Philosophy to Guidance and Counseling As a Science}

Philosophy is the process of seeking the true knowledge of the nature of life and the meaning of life itself in everyday life. The characteristics of philosophist was comprehensive as knowledgeable. An expert with his knowledge he will never be satisfied with information, if only seen from the perspective of science only, but he will seek the truth from the point of view of other sciences to obtain the whole nature of life. From the perspective of this view explains that the man who has this philosophical nature, has a high openness and scientific solidarity, does not consider a science beyond any other science. The next trait is fundamental, meaning that a philosophical person no longer believes in accepting the truth just yet, but will deepen his true question of why the science is true, how the truth criterion is itself, and compile answers that are found from various views. Subsequent trait is speculation, a philosophical person has curiosity and suspicion of an answer and always starts with a question with the intention of introspecting the truth already in his mind and looking for more, so as Plato puts it to discover that knowledge begins with questions of answers given (Suriasumantri, 1985, 2009).

The subject matter studied by philosophy includes three aspects of what is called right and what is called wrong (such an logic common-sense), then the so-called good and the so-called bad (ethics), and who examine beautiful and not beautiful studies of (esthetics). This study in its development became widespread in accordance with the needs and development of human scholarship in seeking the truth using the process of philosophy that is the existence of moral philosophy, philosophy of religion, metaphysical philosophy, philosophy of mathematics, human philosophy (Suriasumantri, 1985).

All forms of philosophy in its development aims to find answers that match the interest of every science and truth that needs to be tested. As Thomas Kuhn notes, the development of science is not derived from the deduction of some common epistemology, but is distinguished from the historical fact of the coming of that knowledge. Although not an epistemology of science, Kuhn describes the significance of epistemology consist of first, it rejects simplisitis and empirical conception of observation. Perception experience can not be the foundation of knowledgeable, because it is a theoretical value reduction, and observation, is the process of generalizing scientific data, not a simple perception (French, 2011: 30). So in that view it explains that every science has its own way of finding answers, though every science in philosophical study equally discovers the truth, but the way to find it differs in epistemology.

As one of the practical disciplines, guidance and counseling is a branch of the philosophical tree of human science that is about the condition of the soul, human behavior and human mind, known as the science of psychology. In the development of guidance and counseling that has had its own method in scientific practice, as well as the approach of experimental methods, qualitative and quantitative. The implications of the development guidance and counseling are more practiced in educational institutions. Educational institutions are institutions of character development for students as a samples of small social systems, before students interact and blend in the social life therefore, the context of self-development and personal formation is axiology of the scientific process of guidance and counseling. The value of counseling is to help clients find their own well-being and counseling should be helping profession like "to help the client through the process of find himself, prepare himself and change himself.

To shape the condition for the individual, the human philosophy focuses on how interaction generates a qualified self condition for communicators and communicants. In this case human philosophy examines the process of dialogue with existing ethical provisions. In the study of the development of classical philosophy of Socrates, Plato and Aristotle have the view that through dialogue and 


\section{COUNS-EDU}

communication is the process of forming good thoughts and attitudes in human social life. This dialogue is known as dialectica, and this activity is called a logical process (Wegmann, 2013: 13). Up to contemporary philosophy that seeks to reform the old thinking on social issues with an understanding of humanistic and postmodernism approaches that prioritize the understanding of human beings as positive and well-being creatures (Hanurawan, 2012: 16), although the dialectical logic of reasoning remains empowered to be one of the approach techniques in counseling psychology.

In the development of human philosophy and become a concept of dialogue counseling that occurs (known by the process of dialectics) is a multidisciplinary that apply the concepts of psychology, sociology, anthropology, education, and philosophy itself. Counseling with practices the logical process of dialectical philosophy has a purpose to shape cognitive thinking of human and has disciplinary ties to the field and especially mental health (Hariko, 2017; Gibson \& Mitchell, 2008).

Guidance and counseling into an independent multidisciplinary science begins with the philosophy of science that is the object of the study of the human being is seen holistically (physical, psychological, cognitive and social interaction) if formulated personal, social, learning, career, and religious guidance. It is ontologically guidance and counseling, and epistemology guidance and counseling into an independent multidisciplinary science can be understand from the way and its application in the process of practice that is using dialectical logic approach to change the mindset and human understanding this is called the therapeutic process as well as qualitative / quantitative behavioral and axiological assessment of guidance and counseling have values and values of science and culture, as well as the existence of communication procedures to build a good counseling relationship so as to build the psychological condition of human (client) to be better and healthier (Hariko, 2017; Suriasumantri, 2009; Geldard \& Geldard, 2005).

\section{Guidance and Counseling Profession in Indonesia}

Guidance and counseling is a multidisciplinary science, in other words, a person who study a counseling must have a first understanding of science from a psychological view; this is because the psychological aspects become the key to building attending in receiving assisted individuals, as well as handling therapy. Second, from a sociological view; this is concerned with building interaction conditions in therapeutic relationships, using language that makes clients comfortable. Third, from an anthropological view; that is related to the understanding of culture and traditions that must be understood in the process of counseling interaction. Fourth, related from a philosophical view; although counseling has separated from philosophy which is a branch from application of psychology in the process of education, philosophy is still coloring the process of counseling, counseling is never separated from logical thinking and invite a clients to logically choose solutions that might be used as a solution for him. (Brammer, 1982; Brammer, 1985; Gibson, 2008).

Counseling become multidisciplinary science and profession, and it does not mean that counseling positions as profession have "multipositioning". In this case the existence of counselors in the national education system is declared as one of the qualifications as educators, like qualifications of teachers, lecturers, and tutors (Law, Number 20/2003, Article 1, Paragraph 6). As well as the explicit recognition and alignment of positions between the qualifications of educators with one another means every educator including the same counselor in the view of educational institutions. In this case the area of the counselor profession is equal to the educator in general and equaled with the qualifications of teachers, lecturers and other educators. Moreover with the guidance and counseling position in the contents of the 2013 Curriculum Educational Standards as self-development for strengthening character education, the performance of teachers need counseling and guidance to realization the strengthening of character education for students in addition to the transfer of knowledge but also need transfer of values. 


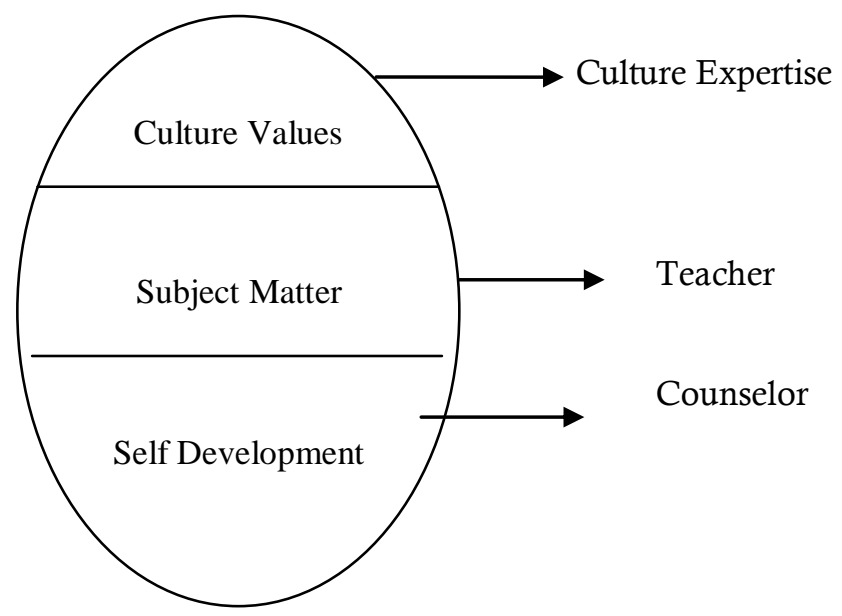

Figure 1. Counseling Position In Circle of Education Standard

This understanding is one of the efforts that need to be practiced in educational institutions in the process of inheritance of positive values to form the right mindset and procedure in the ethical person of the nation. Education is a culture that forms a social system that is practiced in a small environment like a school environment that is a small environment / small sample from a large social system. The social system in education is to shape a students to have a positive and good personal as a personal agent to change the process of student character, this is called agentic personal for other human beings (Bandura, 1986; Bandura, 2001; Bandura, 2006).

Therefore, the profession of guidance and counseling is a fundamental profession in supporting the character education of students in schools. So the area of counselors is in the educational institutions like schools or college. If the constitution says the counselor is an educator, then the counselor should be an example for the students, because the educational institution is a sample of the broad social system of society. If the counselor fails to become an example and supports the educational process of students, then the output of the educational institution will be one deviance that can damage the social system of society, so that the younger generation of Indonesia will experience decadence such character and morals.

If the counseling has been a profession called counselor, for educational conditions like this, it is an improvement. However, it does not mean that counselors can enter other scientific domains, this is clearly outlined in detail in the law on education system No. 20 year 2003 article 1 verse 6 stating that counselors are educators. This context is developed and equated in educational institutions, not community context. This is why it needs to be emphasized because based on the findings in the field of moral damage during the period of 2004-2011 the Ministry of Home Affairs recorded as many as 158 heads of regions were involved in corruption, and 42 members of DPR corruption from 2006-2011 (Kompas, 20 June 2011). As well as in the educational world of prostitution cases among girls, 87\% of junior high school teenagers in Indonesia are not virgin anymore (KOMNAS Perlindungan Anak research results) and 18 female students in West Jakarta have attended as Seks Commercial Worker after back from school (Kartini Magazine, edition 2247/2009).

Based on the case, from 2004 to 2011 declared the condition of the nation's character is very gloomy and dangerous, so the profession of guidance and counseling focuses only in school educational institutions to prevent such behavior, as a character building business. Lack in the shaping of character education is inseparable from the unbridled intelligence, authority, wisdom, and faith of the model in education itself, an educator should be a role model in the school environment. To raise a model and character for students is a necessity, therefore the parents as a model for his son, the teacher as model for his students, lecturers for his students (Alfaiz, 2017: 12). Therefore do not blame the system but start focusing on self-improvement and obligations in accordance with educational regulations that have been declared.

\section{Challenges to Prepare for Future of Guidance and Counseling Profession}

The challenge that will be faced in every development of science in this world is ready for the existence of "extinction" or annihilation and change with new things that replace the old things. In life, this 
term is a process of successive generation, between the old generation and the new generation. At every time has an figure, every figure there is a civilization that is formed, in every civilization there is the science. As Karl Popper illustrates, the challenge of every science in his work the logic of scientific discovery explains that there is a logical process for discovering new konowledge through the process of falsification. In summary, the falsification of Popper's meaning is a science called scientific if it makes a prediction that has a risk of error (in this case scientific knowledge is from the theory that has and is ready to do a discounted confirmation again) (Hanurawan, 2012: 80).

So also with the conditions of scientific guidance and counseling in postmodernism now, that the concept of theory and science of guidance and counseling needs to be prepared in face the challenges and as a scientific science, it is ready with the occurrence of change and adaptation to the demands of civilization and time. So in terms of scientific practice of guidance and counseling, it should be noted the position and application of counseling in the postmodernism or in the 21 st century which is

1. Counseling as a science and profession must understand that the counseling theory stated to be true must admit that in this postmodern period as a narrative structure (structure narrative in communication) that helps restore the client experience with a different meaning from the meaning of previous experience, reorganize the client's understanding and it all depends on how the counselor has the ability to choose a new narrative in communication. Because the concept of modern theory will decline in this modernism (Hansen, 2006: 293).

2. The theory of scientific counseling should be defined as a pragmatic utility, in which case the counseling theory must adapt to the understanding of technological development and even counseling theory can also adapt to situations that put forward the modern society no longer focuses on theory but on the reality that is always relative and even transcendent, the theory of counseling should be pragmatic in interpreting the handling of the client situation at any given moment (Hansen, 2006: 294).

In this view it is clear that theoretical of counseling in general must be ready with eclectic concept, that is not solely theoretical in handling client problem but also can be narrative in interpreting condition of client without base of standard theory to be pragmatic in handling a client problem, it is with the opinion of Goethe German philosopher who said "theory is gray, and real life are green" which has a meaning is if too theoretical in facing the problem in this postmodernism, then counseling will be considered a science that can no longer be relied upon as a profession, then counseling must be ready to be reformed by making modifications in every handling of human problems in this present moment.

In addition about reality that must be prepared in theoretical scholarship, counseling as a science must prepare a generation of science that must be ready to answer the global challenges of citizen (global society). Competencies that are prepared to address these challenges are cultural competencies, which are related to cultural awareness, cultural knowledge, and cultural tolerance schemes; these aspects must be trained for counselor personal (Clarke, 2013: 3). In this view explains the need for empowerment of crosscultural counseling training that must be understood and personal to counselor to make counseling as a multidisciplinary science that is able to adapt and highly utilize in every period and civilization that emerges.

As professionals, counselors as assisting professions should understand that the main focus of counseling is on the educational process within the school environment which is a sample of the social system of the broad social system of society. In this case, the school is a cultural planting of the Indonesian nation is loaded with value, culture and religiosity. So by planting these values in the school's social system, students when in a wide social environment, will not experience negative effects on him when their face a globalization and acculturization.

Globalization, also known as westernization of the world, has the implication that globalization is related to the invasion of western capitalism into the developing world and influences the world idealism to fit the context of western cultural thinking (Lorelle et al., 2012: 115). It aims to homogenize the concept of western tradition to all areas of world life, it is also a challenge for counseling science especially for counselors in Indonesia, if there is acculturization and cultural blending it will be eroded the noble values of the eastern Indonesia that has been since 2010 proclaimed character education and mental revolution by purified to the value of Pancasila. 
In this globalization, there is the concept of liberation counseling formulated by Paulo Freire in Brazil, whose original idea was simply to practice to free the conditions of the poor and oppressed society of the time. But in its development, the logic of liberation counseling is interpreted in a broad context as in education. Freire and colleagues set out the view that in the education the student is the subject in the learning process rather than the object, as they are the subject then their should determine their own destiny, and convey that the objective of learning as their learning process to free participants from the external appreciation (teacher and values) as well as the internal appreciation (true desire) and facilitate the students to be able to change their lives and the surrounding community (Freire, 1971).

This concept will be detrimental in the process of education and learning in Indonesia, as a country that still builds the process of character and noble values of the nation. Freire's opinion will undermine the educational order and noble values of the nation, when the government regulations on curriculum are established, formulated and applied by educator, there are still found students and educators are not maximized in teaching and learning and there are many irregularities in education and learning and deviant behavior, education. With the mindset of liberation, of course the character of the nation can be dilapidated. The concept of liberation is a concept that states and world order are confinement for every individual to find himself in learning, so that if this concept blending in globalization and homogenize the world with the concept of non-rules, the true order in character values of Indonesia will distinguish.

These are challenges that must be tackled and faced by counselors. Therefore, the counselor as an educator profession should focus on how to support the educational process with curriculum that have been based on the value of Pancasila which is the noble value of the nation and helps shape the character of students through a humanistic and religious approach. In order for students to have a good social life experience in the school environment

Putting aside the thought of counseling outside the school and community, unless there is already a rule of law that states counselors also have an obligation to support and help shape the character of society, but it will not be possible. Because every man has his time, and every time there is civilization and every civilization there is a science and every science has its own territory. Therefore none of a science has overlapping with other areas of science. If it exists then the ontology, epistemology, and axiology must be explore once more.

\section{Conclussion}

Based on the discussion in the previous, we can draw the conclusion which is the core of all our discussion on the previous page, can be divided into several points:

1. Guidance and counseling not only as an independent and multidisciplinary science, but also as a very value-filled and adaptive science in the development of the times.

2. Guidance and counseling is a very useful science in education, especially to form logically human according to what they want. The philosophical view of guidance and counseling is the view that occurs in the therapeutic dialetical process in the counseling process. So guidance and counseling are loaded with philosophical processes.

3. The profession of guidance and counseling is recognized by the Indonesian government as an educator profession called a counselor. The counselor has the responsibility to support the learning process and help the government program strengthen the character education of students. Because educational institutions are a small sample of social systems.

4. The challenge to the profession of counseling as a helping profession is very heavy with the condition of postmodernism, acculturation of culture, the globalization of society and the globalization of liberation thinking. This should be made by a strategy by counselor to minimize negative influences for a students and community.

\section{Acknowledgment}

This article cannot be separated from the support and collaboration of the all author, that has been give contribution, as well as the authors also thank to the Counsedu Journal and the editorial board, Mr. Ifdil, SH.I, S.Pd, M.Pd, Ph.D that facilitates in publication of this article as a contribution of the theoretical concept for counseling profession. 


\section{References}

Alfaiz. (2017). "Kepribadian Aspek Penting Dalam Pendidikan". Buletin Pintu. KOPERTIS Wilayah X Sumbar, Riau, Jambi \& Kepri. ISSN: 2087-2232. Hal. 12.

ALFAIZ, A. (2015). Pembelajaran Afektif Merupakan Salah Satu Strategi Dalam Pembentukan Karakter Peserta Didik (Sebuah Tinjauan dari Perspektif Psikologi; Social Cognitive Theory). Jurnal Pelangi, $7(1)$.

Alfaiz, A., \& Yandri, H. (2015). Self concept and self efficacy as a ground points in a social activities (an analysis of psychology perspective: a social cognitive theory). Jurnal Pelangi, 7(2).

Alfaiz. (2017). Sufism Approached in School Counseling Service: An Analysis of Perspective Spiritual Counseling. Jurnal Schoulid: Indonesian Journal of School Counseling. Vol. 2, No. 1. https://doi.org/10.23916/008621423-00-0.

http://journal.konselor.or.id/index.php/schoulid/article/view/42

Faiz, A., Dharmayanti, A., \& Nofrita, N. (2018). Etika Bimbingan dan Konseling dalam Pendekatan Filsafat Ilmu. Indonesian Journal of Educational Counseling, 2(1), 1-12. https://doi.org/10.30653/001.201821.26.

http://ijec.ejournal.id/index.php/counseling/article/view/26

Bandura, Albert. 1986. "Social Foundation of Thought and Action: Social Cognitive Theory". Englewood Cliffs, New Jersey: Prentice-Hall.

Bandura, Albert, 2001. "Social Cognitive Theory: An Agentic Perspective". Annual Review Psychological, Vol $52,1-26$.

Bandura, Albert, 2006. "Toward a Psychology of Human Agency". American for Psychological Science. Vol. 1, No. 2, 164-180.

Brammer, L and Shostrom, E. 1982. Therapeutic Psychology; Fundamental of Counseling and Psychotherapy. Fourth Edition. Prentice Hall: New Jersey

Brammer, Alison. 2014. "Introduction". In Safeguarding Adults, 1-19. Macmillan Education UK. doi:10.1007/978-1-137-28996-4_1.

Clarke. T,S. (2013). "Multicultural Counseling Competencies: Extending Multicultural Training Paradigms Toward Globalization". Ideas and Research VISTAS.

French, S \& Saatsi, J. (2011). "The Continuum Companion The Philosophy of Science". Continuum International Publishing: London

Geldard, K \& Geldard, D. (2005). "Practical Counselling Skills: An Integrative Approach". Palgrave Mac Millan.

Gibson, R. L \& Mitchell, (2008). "Guidance and Counseling Theory”. Pustaka Setia. Jakarta

Hansen. J. T. (2006). "Counseling Theories Within a Postmodernist Epistemology: New Roles for Theories in Counseling Practice". Journal of Counseling \& Development, Vol. 84. ACA.

Hanurawan, Fattah. (2012). "Filsafat Ilmu Psikologi". Fakultas Pendidikan Psikologi, Universitas Negeri Malang.

Hariko, Rezki. (2017). "Landasan Filosofis Keterampilan Komunikasi Konseling". Jurnal Kajian Bimbingan dan Konseling (JKBK). Vol. 2 (2), Hal. 41-49.

Lorelle, S., Byrd, R., \& Crockett. (2012). "Globalization and Counseling: Professional Issues for Counselors". The Professional-Counselor: Research and Practice. Vol. 2, Issue 2. Page: 115-123

Suriasumantri, J.S. (1985). "Filsafat Ilmu: Sebuah Pengantar Populer". Jakarta : Pustaka Sinar Harapan.

Suriasumantri, J.S. (2009). "Ilmu Dalam Perspektif”. Jakarta : Yayasan Obor Indonesia.

Wegmann, Mathew. (2013). "Philosophy and Counseling: A Case Study". Scholar Works. University of New Orleans. 